\title{
Disparate SAR Data of Griseofulvin Analogues for the Dermatophytes Trichophyton mentagrophytes, T. rubrum, and MDA-MB-231 Cancer Cells
}

Rønnest, Mads Holger; Raab, Marc S.; Anderhub, Simon; Boesen, Sven; Krämer, Alwin; Larsen, Thomas Ostenfeld; Clausen, Mads Hartvig

Published in:

Journal of Medicinal Chemistry

Link to article, DOI:

$10.1021 / \mathrm{jm} 200835 \mathrm{c}$

Publication date:

2012

Document Version

Publisher's PDF, also known as Version of record

Link back to DTU Orbit

Citation (APA):

Rønnest, M. H., Raab, M. S., Anderhub, S., Boesen, S., Krämer, A., Larsen, T. O., \& Clausen, M. H. (2012).

Disparate SAR Data of Griseofulvin Analogues for the Dermatophytes Trichophyton mentagrophytes, T. rubrum, and MDA-MB-231 Cancer Cells. Journal of Medicinal Chemistry, 55(2), 652-660.

https://doi.org/10.1021/jm200835c

\section{General rights}

Copyright and moral rights for the publications made accessible in the public portal are retained by the authors and/or other copyright owners and it is a condition of accessing publications that users recognise and abide by the legal requirements associated with these rights.

- Users may download and print one copy of any publication from the public portal for the purpose of private study or research.

- You may not further distribute the material or use it for any profit-making activity or commercial gain

- You may freely distribute the URL identifying the publication in the public portal 


\title{
Journal of

\section{Disparate SAR Data of Griseofulvin Analogues for the Dermatophytes Trichophyton mentagrophytes, T. rubrum, and MDA-MB-231 Cancer Cells}

\author{
Mads H. Rønnest, ${ }^{\dagger,}$ Marc S. Raab, ${ }^{\S}, \|$ Simon Anderhub, " Sven Boesen, \\ Thomas O. Larsen, ${ }^{*} \neq$ and Mads H. Clausen $* \dagger$ \\ ${ }^{\dagger}$ Center for Nanomedicine and Theranostics \& Department of Chemistry, Technical University of Denmark, Kemitorvet, \\ Building 201, DK-2800 Kgs. Lyngby, Denmark \\ ${ }^{\ddagger}$ Center for Microbial Biotechnology, Department of Systems Biology, Søltofts Plads, Building 221, DK-2800 Kgs. Lyngby, Denmark \\ ${ }^{\S}$ Max-Eder Group “Experimental Therapies for Hematologic Malignancies”, German Cancer Research Center (DKFZ) and \\ Department of Internal Medicine V, University of Heidelberg, Im Neuenheimer Feld 280 (TP4), 69120 Heidelberg, Germany \\ "Clinical Cooperation Unit Molecular Hematology/Oncology, German Cancer Research Center (DKFZ) and Department of Internal \\ Medicine V, University of Heidelberg, Im Neuenheimer Feld 280 (TP4), 69120 Heidelberg, Germany
}

\section{Supporting Information}

ABSTRACT: Griseofulvin and 53 analogues of this compound have been tested against the pathogenic dermatophytes Trichophyton rubrum and Trichophyton mentagrophytes as well as against the breast cancer cell line MDA-MB-231. The modifications to griseofulvin include the $4,5,6,2^{\prime}, 3^{\prime}$, and $4^{\prime}$ positions. The SAR of the griseofulvin analogues toward the two fungi followed the same trend with the majority being less active than griseofulvin and none had more than twice the potency of the parent compound. A comparison of the antifungal and the anticancer SAR revealed distinct differences, as the majority of analogues showed increased activity against the cancer cell line MDA-MB-231, highlighted by 2'-benzyloxy-2'-demethoxy-griseofulvin, which showed low activity against both fungi but was among the most potent compounds against MDA-MB-231 cancer cells. Tubulin has been proposed as the target of griseofulvin in both fungal and mammalian cells, but the differences revealed by this SAR study strongly suggest that the mode-of-action of the compound class toward fungi and mammalian cancer cells is different.

\section{INTRODUCTION}

Griseofulvin (1, see Figure 1) was one of the first antifungal natural products isolated ${ }^{1}$ from filamentous fungi and has been

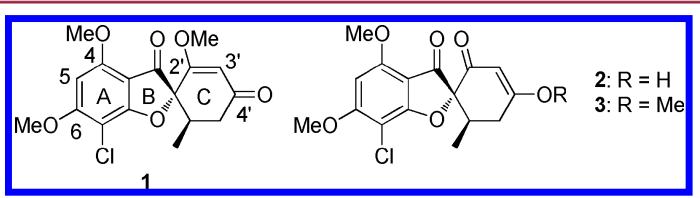

Figure 1. The structure of griseofulvin (1), griseofulvic acid (2), and isogriseofulvin (3). The rings $\mathrm{A}, \mathrm{B}$, and $\mathrm{C}$ as well as the positions modified in this study in $\mathbf{1}$ are shown.

known as an antifungal agent for decades. ${ }^{2,3}$ The compound was, until the approval of Terbinafine ${ }^{4}$ by the US Food and Drug Administration ${ }^{5}$ in 2007, the only drug available for treatment of tinea capitis, ${ }^{6}$ a superficial fungal skin infection caused by dermatophytes, which predominantly affects children. ${ }^{7}$ Upon administration to man, griseofulvin accumulates in the skin (stratum corneum), where it presumably binds to keratin. ${ }^{8}$ The mode of action is still not determined, but tubulin binding has been proposed.,
More than 400 griseofulvin analogues have been reported since its discovery, and the activity of over 300 of these have been compared with griseofulvin (1) against six dermatophytes in a study by Crosse et al. ${ }^{11}$ The curling of hyphae in Botrytis allii were also tested, but this phenotype did not correlate with the growth inhibitory effect of the analogues. ${ }^{11}$ Griseofulvin analogues with modifications at positions $4,6,2^{\prime}$, and $3^{\prime}$ as well as isogriseofulvin analogues with modifications at the 4, 6, 3', and 4 ' positions were tested. No 2 ' analogues excelled in growth inhibition of the dermatophytes, ${ }^{11}$ but elongation did increase the curling of hyphae with the optimal analogues being 2 '-propoxy (46) and 2'-butoxy analogues. ${ }^{12}$ Most griseofulvin analogues tested showed increased potency against some dermatophytes but exhibiting lower activity against others.

Position 5 has been functionalized with nitro (9) and amine (10) groups, rendering the analogues inactive at relevant concentrations against four dermatophytes. ${ }^{13}$ An ethoxycarbonyl group has also been introduced in this position and the analogue found to be inactive. ${ }^{14}$ The $4^{\prime}$ position has also been

Received: June 27, 2011

Published: December 19, 2011 
examined with the $4^{\prime}$ alcohol analogue $(50)$ being inactive and the $4^{\prime}$ oxime (36) being 7 -fold less potent compared to 1 , with both analogues tested against Microsporum gypseum. ${ }^{15}$

Although the initial isolation of 1 was completed in 1939, ${ }^{1}$

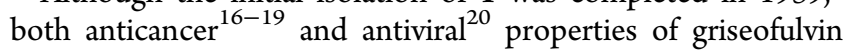
have been discovered recently. Three analogues tested for the former by Oda et al. ${ }^{21}$ against chinese hamster V79 cells showed increased cytotoxicity, with 2'-propoxy-2'demethoxygriseofulvin being the most potent $\left(46, \mathrm{IC}_{50} 0.7 \mu \mathrm{M} ; 1,8 \mu \mathrm{M}\right)$, and it was proposed that additional structural modifications at the $2^{\prime}$ position could enhance activity further. This was supported by ourselves in a whole-cell phenotype-based anticancer assay for spindle multipolarity induction, where increased activity was seen for analogues with modifications in the $2^{\prime}$ position, with the 2'-benzyloxy-2'-demethoxy-griseofulvin analogue (17) being the most potent compound tested. ${ }^{22}$ Multiple papers state that griseofulvin arrests several cancer cell lines in $\mathrm{G}_{2} / \mathrm{M}$ phase of the cell cycle. ${ }^{17-19}$ Several investigators have proposed tubulin as the main target for griseofulvin, although for mammalian cells this suggestion is not undisputed. ${ }^{9,17,18,20,21,23,24}$ Recently, Panda et al. ${ }^{25}$ proposed two griseofulvin binding sites on tubulin using molecular docking studies and similar to Oda ${ }^{21}$ reported that microtubule dynamics were disrupted by 1 . Using the hepatitis $C$ virus- $1 b$ cell culture system Huh7/Rep-Feo, Jin et al. reported that $\mathrm{G}_{2} / \mathrm{M}$ phase arrest in infected cells was induced by griseofulvin $(\mathbf{1}){ }^{20}$ It was speculated that the effect was due to interaction with microtubule polymerization. ${ }^{20}$

Griseofulvin exhibits activity against fungi and mammalian cancer cells as well as suppressing RNA replication by the hepatitis $\mathrm{C}$ virus, with tubulin having been proposed to be involved in all three cases. Tubulins are very conserved within different eukaryotic cell types, ${ }^{24}$ and most of the variation among different tubulin isoforms is found in the amino acids near the C-terminus, which form a ridge on the surface of microtubules. Therefore, variations among different isoforms are expected to affect primarily the association of accessory proteins with the surface of microtubules rather than microtubule polymerization per se. In case tubulin is the sole target of griseofulvin in both fungi and mammalian cells, the activity profile of an array of analogues against these cell types should be similar. To test this hypothesis, we decided to carry out an SAR study of griseofulvin analogues. This is, to the best of our knowledge, the first study of griseofulvin (1) and analogues thereof which compares antifungal and anticancer SAR from growth inhibition assays.

Griseofulvin (1) and 54 griseofulvin analogues (11 reported for the first time here) have been tested in an antifungal assay against Trichophyton mentagrophytes and Trichophyton rubrum, two dermatophytes causing tinea capitis. ${ }^{7}$ All compounds were also tested in an anticancer assay against the human cell line MDA-MB-231 (breast adenocarcinoma), which was chosen because this cell line represents a common cancer type and is known to harbor supernumerary centrosomes which are regularly clustered into a bipolar mitotic spindle array in a high percentage of cells. ${ }^{26}$ All analogues, having alterations at the 4 , $5,6,2^{\prime}, 3^{\prime}$, and $4^{\prime}$ positions, have been synthesized from commercially available griseofulvin in one to five synthetic steps, as described here or following published procedures.

\section{RESULTS AND DISCUSSION}

Chemistry. The 4-phenol (4) was synthesized from 1 by treatment with freshly prepared $\mathrm{MgI}_{2}$, procured by sonication of $\mathrm{Mg}$ and $\mathrm{I}_{2}$ in $\mathrm{Et}_{2} \mathrm{O} /$ toluene, affording 4 in $99 \%$ yield, an improvement on prior methods (Scheme 1). ${ }^{22,27}$ Alkylation of 4 to synthesize 5 and $\mathbf{6}$ has previously been described. ${ }^{22,27}$

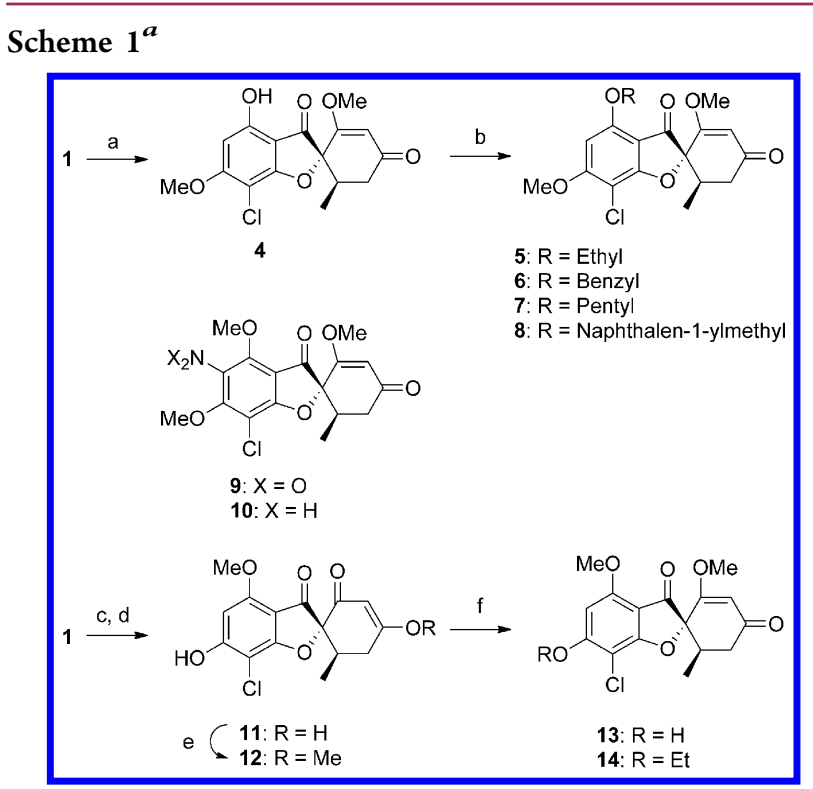

a (a) $\mathrm{MgI}_{2}$, toluene, $\mathrm{Et}_{2} \mathrm{O}$; (b) $\mathrm{RBr}, \mathrm{Ag}_{2} \mathrm{O}$, dioxane; (c) HOAc, $2 \mathrm{M}$ $\mathrm{H}_{2} \mathrm{SO}_{4}$; (d) $0.66 \mathrm{M} \mathrm{NaOH}$; (e) $\mathrm{MeOH}, \mathrm{CSA}$; (f) $\mathrm{MeOH}, \mathrm{CSA}$ (13) or $\mathrm{EtBr}, \mathrm{Ag}_{2} \mathrm{O}$, dioxane, then $\mathrm{MeOH}, \mathrm{CSA}(14)$.

Position 4 analogues 7 and 8 were prepared from 4 with $\mathrm{Ag}_{2} \mathrm{O}$ and the appropriate alkyl bromide in dioxane as solvent. ${ }^{27}$ The syntheses of 9 and 10 have already been described. ${ }^{22,28}$

For the preparation of 11,12 , and 13, see Rønnest et al. ${ }^{29}$ and Arkley et al. ${ }^{27}$ Compound 12 was alkylated using $\mathrm{Ag}_{2} \mathrm{O}$ and $\mathrm{EtBr}$ followed by repeated solvolysis in $\mathrm{MeOH}$ with camphor sulfonic acid (CSA) to afford 14. The dichloro analogues 15 and 16 were synthesized using $2,{ }^{30} \mathrm{POCl}_{3}, \mathrm{LiCl}$, and dioxane, a modification of a known method (Scheme 2). ${ }^{31}$ The

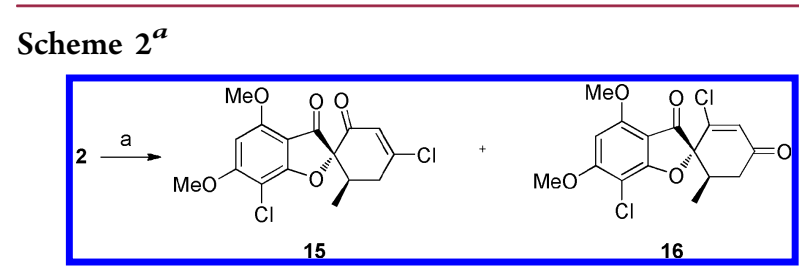

${ }^{a}(\mathrm{a}) \mathrm{LiCl}, \mathrm{POCl}_{3}$, dioxane.

compounds 17-33 were synthesized by 1,4-addition of the corresponding alcohol to 16 using either $\mathrm{NaH}$ or 1,8-diazabicyclo[5.4.0] undec-7-ene (DBU) as base (Scheme 3). ${ }^{31}$ The isogriseofulvin analogues 3 and 35 were synthesized in the same manner but from 15. Compound 3 has previously been prepared by treating 2 with excess diazomethane, yielding both 1 and $3 .^{32}$ Compounds 26 and 38 have been reported in a patent, ${ }^{33}$ which is also the case for 19,21 , and $22 .{ }^{34}$ The dimer 34 , which was conveniently synthesized together with 22 by a second 1,4-addition of 22 to 16, has previously been published in a Japanese patent. $^{35}$

The analogues with an oxime functionality 36,37 , and 38 were synthesized from the corresponding ketones (1, 17, and 26) using hydroxylamine hydrochloride in ethanol and DMSO. ${ }^{13,22}$ Isogriseofulvin (39-44) and griseofulvin analogues (45-49 and 17) were synthesized simultaneously in pairs by solvolysis 


\section{Scheme $3^{a}$}

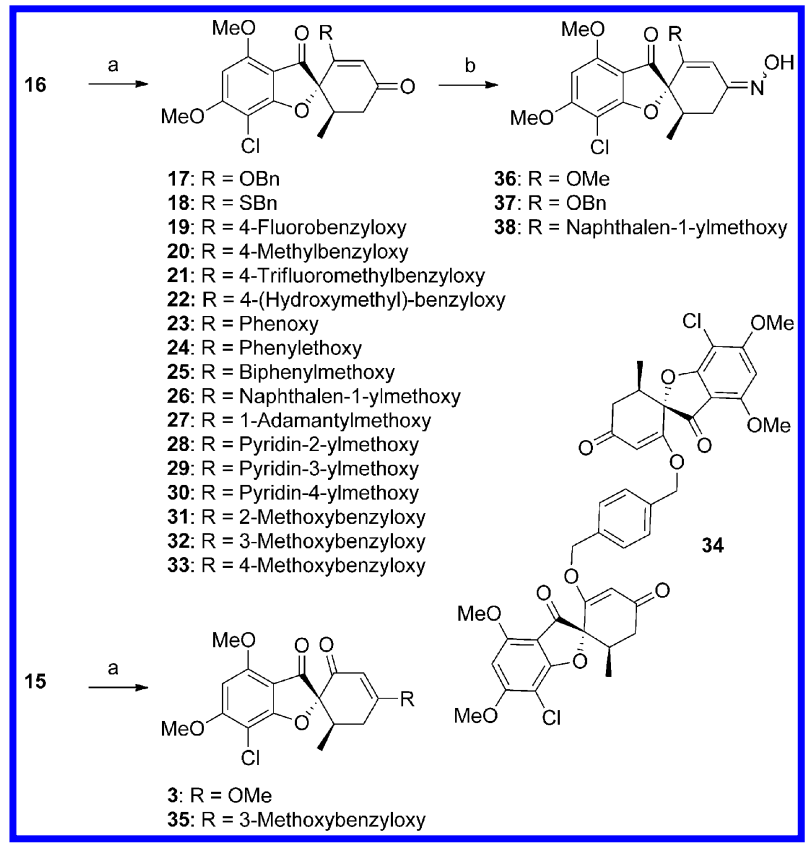

${ }^{a}$ (a) RH, DBU, THF, or dioxane; (b) hydroxylamine, NaOAc, EtOH, DMSO.

with the respective alcohols and catalytic CSA and subsequently separated by chromatography (Scheme 4).

\section{Scheme $4^{a}$}

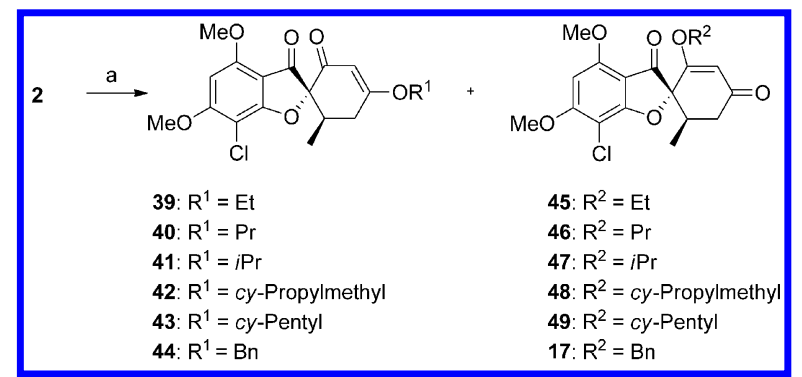

a (a) ROH, CSA, dioxane $(17,42-44,48$, and 49).

Analogues 50-55 were synthesized according to published procedures (Figure 2). ${ }^{22}$ The fungal secondary metabolite geodin (56) was recently isolated from Aspergillus terreus. ${ }^{36}$ Please see the Supporting Information for experimental details and spectral data.

Assays. Griseofulvin (1), geodin (56), and 53 griseofulvin analogues covering variations on six positions (see Figure 1) were tested against two dermatophytes (T. rubrum and T. mentagrophytes) and against the breast cancer cell line MDAMB-231 in a cytotoxicity assay. For all the test results the following definitions were used: if no activity was observed at $50 \mu \mathrm{M}$, a given compound was deemed inactive; if activity was observed but $50 \%$ inhibition was not reached at $50 \mu \mathrm{M}$, a given compound is described as having low activity and no $\mathrm{IC}_{50}$ value is calculated (see Supporting Information for examples). The $\mathrm{IC}_{50}$ of griseofulvin (1) was determined to be $0.38 \pm 0.048 \mu \mathrm{M}$ against the T. rubrum isolate and $0.058 \pm 0.018 \mu \mathrm{M}$ against the T. mentagrophytes isolate. All $\mathrm{IC}_{50}$ values and $95 \%$ confidence intervals are given in Table 1. All dilution series were made starting with $50 \mu \mathrm{M}$ of the tested compound in order to ensure

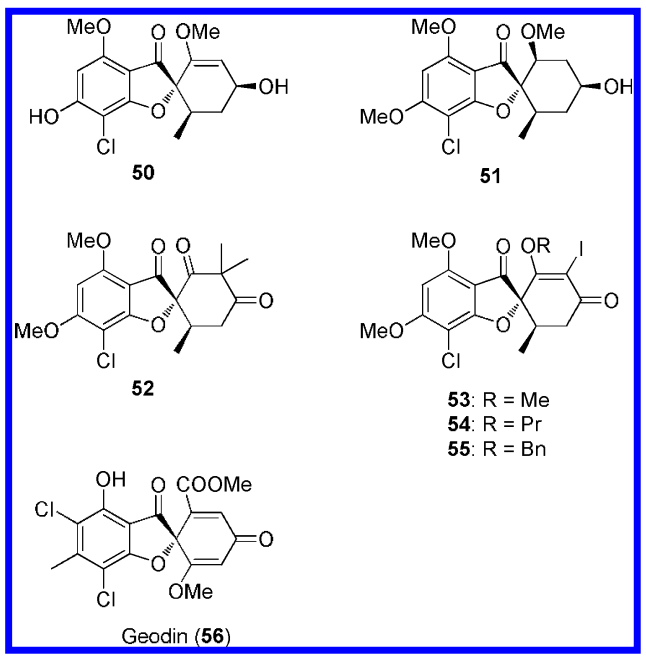

Figure 2. The analogues $\mathbf{5 0 - 5 5}$ were prepared according to literature procedures. ${ }^{22}$ Geodin (56) was isolated as previously described. ${ }^{36}$

that all compounds were soluble in the assay media, which for some compounds were not the case at higher concentrations.

Antifungal SAR for T. rubrum and T. mentagrophytes. All compounds in the position 4 series of 4-8 were less active than griseofulvin (1) against the two fungi and 8 was completely inactive. For T. rubrum, 4 and 6 were inactive, 7 had low activity, and 5 was, with an $\mathrm{IC}_{50}$ of $2.0 \mu \mathrm{M}$, approximately five times less potent than griseofulvin. For T. mentagrophytes, analogue 4 showed low activity and the rest were less potent than 1 : $5(0.29 \mu \mathrm{M}), 6(0.25 \mu \mathrm{M})$, and 7 $(0.17 \mu \mathrm{M})$. The activity of 6 has previously been reported against a number of dermatophytes (Epidermophyton floccosum, Microsporum canis, Trichophyton interdigitale, Trichophyton persicolor, T. mentagrophytes, and T. rubrum) and found to be less active than 1 against all of them. ${ }^{11}$

The nitro (9) and amine (10) position 5 analogues were inactive against both fungi. Compound $\mathbf{1 0}$ has also been reported as inactive, but $\mathbf{9}$ has been reported as weakly active with inhibition for both fungi starting at around $25 \mu \mathrm{M} .{ }^{13}$ Other position 5 analogues (ethoxycarbonyl, ${ }^{14}$ methoxy, methyl, or chloro $^{37}$ ) have been reported to have lower activity than $\mathbf{1}$ against dermatophytes.

Whereas the position 6 phenols 13 and 11 were inactive against both fungi, the 6-ethyl analogue (14) had an $\mathrm{IC}_{50}$ of $1.3 \mu \mathrm{M}$ against T. rubrum and was as active as griseofulvin (1) against T. mentagrophytes with an $\mathrm{IC}_{50}$ of $0.062 \mu \mathrm{M}$, which is in accordance with the literature. ${ }^{11}$

The 2 ' series is the most extensively studied due to the increased activity observed in the anticancer phenotype-based assay ${ }^{19}$ by these analogues. For T. rubrum, elongation to $2^{\prime}$ ethyloxy $(45,0.69 \mu \mathrm{M})$ and 2'-propyloxy $(46,0.62 \mu \mathrm{M})$ lowered the activity 2 -fold, confirming the findings of Crosse et al. ${ }^{11}$ The bulkier 2 -isopropyloxy $(47,3.1 \mu \mathrm{M})$ was 10 times less potent. Increasing bulkiness through 2'-cyclopropylmethoxy (48, $1.5 \mu \mathrm{M})$, cyclopentyloxy $(49,2.5 \mu \mathrm{M})$, and benzyloxy (17, $1.1 \mu \mathrm{M})$ enol ethers did not reveal a trend, but all three were less active toward T. rubrum than $\mathbf{1}$. No correlation between the size of the 2 ' substituent and the activity was seen for T. mentagrophytes with $46(0.050 \mu \mathrm{M})$ retaining the activity of 1 and $\mathrm{IC}_{50}$ values of $0.25 \mu \mathrm{M}$ and $0.11 \mu \mathrm{M}$ for 45 and 47, respectively. Both 45 and 46 have been reported to retain the activity of $\mathbf{1}$ against $T$. mentagrophytes by Crosse et al. ${ }^{11}$ 
Table 1. All Available $\mathrm{IC}_{50}$ Values from the Screen ${ }^{a}$

\begin{tabular}{|c|c|c|c|c|c|c|}
\hline $\begin{array}{c}\text { Cmp. } \\
\text { no. }\end{array}$ & $\begin{array}{l}\text { T. rubrum } \\
(\mu \mathrm{M})\end{array}$ & $\begin{array}{c} \pm \text { STD } \\
\mathrm{IC}_{50} \\
(\mu \mathrm{M})\end{array}$ & $\begin{array}{l}\text { T. menta- } \\
\text { grophytes } \\
\quad(\mu \mathrm{M})\end{array}$ & $\begin{array}{c} \pm \mathrm{STD} \\
\mathrm{IC}_{50} \\
(\mu \mathrm{M})\end{array}$ & $\begin{array}{c}\text { cytotox } \\
(\mu \mathrm{M})\end{array}$ & $\begin{array}{c} \pm \text { STD } \\
\text { IC }_{50} \\
(\mu \mathrm{M})\end{array}$ \\
\hline 1 & 0.38 & 0.05 & 0.058 & 0.02 & 18 & 4 \\
\hline 2 & inactive & inactive & low activity & & inactive & inactive \\
\hline 3 & inactive & inactive & inactive & inactive & inactive & inactive \\
\hline 4 & inactive & inactive & low activity & & inactive & inactive \\
\hline 5 & 2.0 & 0.7 & 0.29 & 0.1 & inactive & inactive \\
\hline 6 & inactive & inactive & 0.25 & 0.009 & 20 & 4 \\
\hline 7 & low activity & & 0.17 & 0.02 & low activity & \\
\hline 8 & inactive & inactive & inactive & inactive & 17 & 2 \\
\hline 9 & inactive & inactive & inactive & inactive & inactive & inactive \\
\hline 10 & inactive & inactive & inactive & inactive & inactive & inactive \\
\hline 11 & inactive & inactive & inactive & inactive & inactive & inactive \\
\hline 13 & inactive & inactive & inactive & inactive & low activity & \\
\hline 14 & 1.3 & 0.1 & 0.062 & 0.02 & 36 & 3 \\
\hline 15 & inactive & inactive & inactive & inactive & 1.0 & 0.1 \\
\hline 16 & low activity & & low activity & & 3.2 & 0.3 \\
\hline 17 & 1.1 & 0.2 & 0.26 & 0.1 & 2.1 & 0.2 \\
\hline 18 & 1.3 & 0.4 & 0.058 & 0.02 & 4.7 & 0.7 \\
\hline 19 & 0.83 & very wide & 0.041 & 0.01 & 6.5 & 1 \\
\hline 20 & 1.0 & 0.2 & 0.24 & 0.1 & 1.8 & 0.3 \\
\hline 21 & 1.5 & 0.2 & 0.15 & 0.1 & 7.0 & 0.9 \\
\hline 22 & low activity & & 1.7 & 1 & 2.8 & 0.6 \\
\hline 23 & 6.1 & 7 & 1.6 & 3 & 7.2 & 1 \\
\hline 24 & low activity & & 0.28 & 0.2 & 17 & 2 \\
\hline 25 & inactive & inactive & inactive & inactive & 5.8 & 1 \\
\hline 26 & 2.6 & 0.3 & 0.25 & 0.09 & 13 & 2 \\
\hline 27 & inactive & inactive & inactive & inactive & 4.7 & 0.5 \\
\hline 28 & low activity & & 1.3 & 3 & 32 & 6 \\
\hline 29 & low activity & & 0.35 & 0.2 & 10 & 2 \\
\hline
\end{tabular}

\begin{tabular}{|c|c|c|c|c|c|c|}
\hline $\begin{array}{c}\text { Cmp. } \\
\text { no. }\end{array}$ & $\begin{array}{l}\text { T. rubrum } \\
(\mu \mathrm{M})\end{array}$ & $\begin{array}{r} \pm \quad \text { STD } \\
\mathrm{IC}_{50} \\
(\mu \mathrm{M})\end{array}$ & $\begin{array}{c}\text { T. menta- } \\
\text { grophytes } \\
(\mu \mathrm{M})\end{array}$ & $\begin{array}{r} \pm \mathrm{STD} \\
\mathrm{IC}_{50} \\
(\mu \mathrm{M})\end{array}$ & $\begin{array}{r}\text { cytotox } \\
(\mu \mathrm{M})\end{array}$ & $\begin{array}{r} \pm \mathrm{STD} \\
\mathrm{IC}_{50} \\
(\mu \mathrm{M})\end{array}$ \\
\hline 30 & low activity & & low activity & & 19 & 2 \\
\hline 31 & low activity & & 0.70 & 0.6 & 11 & 3 \\
\hline 32 & 0.96 & 0.4 & 0.14 & 0.07 & 8.1 & 2 \\
\hline 33 & inactive & inactive & inactive & inactive & low activity & - \\
\hline 34 & inactive & inactive & inactive & inactive & 8.5 & 2 \\
\hline 35 & inactive & inactive & low activity & & 25 & 5 \\
\hline 36 & 1.3 & 0.5 & 0.19 & 0.1 & 12 & 2 \\
\hline 37 & 7.9 & 0.9 & 0.30 & 0.2 & 1.4 & 0.3 \\
\hline 38 & inactive & inactive & inactive & inactive & 8.3 & 0.8 \\
\hline 39 & inactive & inactive & low activity & & low activity & \\
\hline 40 & inactive & inactive & low activity & & 43 & 6 \\
\hline 41 & inactive & inactive & low activity & & 48 & 10 \\
\hline 42 & inactive & inactive & low activity & & 52 & 10 \\
\hline 43 & inactive & inactive & low activity & & 27 & 4 \\
\hline 44 & inactive & inactive & low activity & & low activity & \\
\hline 45 & 0.69 & 0.2 & 0.25 & 0.08 & 13 & 3 \\
\hline 46 & 0.62 & 0.09 & 0.050 & 0.02 & 16 & 5 \\
\hline 47 & 3.1 & 1 & 0.11 & 0.05 & 11 & 3 \\
\hline 48 & 1.5 & 0.3 & 0.060 & 0.02 & 9.4 & 2 \\
\hline 49 & 2.5 & 0.8 & 0.24 & 0.09 & 3.2 & 0.5 \\
\hline 50 & low activity & & low activity & & inactive & inactive \\
\hline 51 & low activity & & 3.0 & 1 & inactive & inactive \\
\hline 52 & inactive & inactive & inactive & inactive & inactive & inactive \\
\hline 53 & inactive & inactive & low activity & & 22 & 1 \\
\hline 54 & 1.6 & 0.4 & 0.23 & 0.08 & 8.0 & 1 \\
\hline 55 & inactive & inactive & 1.1 & 0.5 & low activity & \\
\hline 56 & inactive & inactive & inactive & inactive & 9.9 & 1 \\
\hline
\end{tabular}

${ }^{a}$ If no activity was observed at $50 \mu \mathrm{M}$, a given compound is deemed inactive. If activity was observed, but $50 \%$ inhibition was not reached at $50 \mu \mathrm{M}$, a given compound is described as having low activity and the $\mathrm{IC}_{50}$ value is not calculated.

Analogue $48(0.060 \mu \mathrm{M})$ had the same activity as $\mathbf{1}$, but $\mathbf{1 7}$ $(0.26 \mu \mathrm{M})$ and $49(0.24 \mu \mathrm{M})$ were about four times less potent.

The activities of 17,45 , and 46 have been reported against T. mentagrophytes and T. rubrum, and all showed lower activity when tested against the latter. ${ }^{11}$ Lower activity than $\mathbf{1}$ toward T. mentagrophytes was also reported for 17 , but 45 and 46 had similar potency. ${ }^{11}$ The three compounds were also tested against E. floccosum, M. canis, T. interdigitale, and T. persicolor displaying the same trends, with $\mathbf{1 7}$ having lower activity and 45 and 46 retaining the activity of $1 .^{11}$

The rest of the $2^{\prime}$ series includes bulkier analogues (25-27), para-substituted variations of 17 (19-22), two sets of ortho-, meta-, and para-analogues (28-30 and 31-33), modification of the linker part (23 and 24 ), and a vinyl sulfide analogue 18 .

Of the bulkier 2 ' analogues, the naphthalen-1-ylmethoxy 26 was the only active analogue and 25 and 27 were inactive against both fungi. With $\mathrm{IC}_{50}$ values of $2.6 \mu \mathrm{M}$ (T. rubrum) and $0.25 \mu \mathrm{M}$ (T. mentagrophytes), compound 26 is three and four times less potent than 1 , respectively.

The three $2^{\prime}$ pyridine analogues $(\mathbf{2 8 - 3 0})$ had low activity toward T. rubrum, and $\mathbf{3 0}$ also showed low activity toward T. mentagrophytes. Compounds $\mathbf{2 8}$ and $\mathbf{2 9}$ had $\mathrm{IC}_{50}$ values of 1.3 and $0.35 \mu \mathrm{M}$, meaning they were approximately 22 and 6 times less potent toward T. rubrum compared to 1 , respectively. The series with ortho-, meta-, and para-methoxy groups revealed 33 as inactive against both fungi, 31 with low activity toward T. rubrum and an $\mathrm{IC}_{50}$ of $0.70 \mu \mathrm{M}$ against $T$. mentagrophytes.
The meta-substituted analogue $32(0.96 \mu \mathrm{M})$ was 3-fold less active against T. rubrum compared to 1 and displayed a 2 -fold decrease in activity against $T$. mentagrophytes with an $\mathrm{IC}_{50}$ of $0.14 \mu \mathrm{M}$.

The 2'-phenoxy analogue (23) had $\mathrm{IC}_{50}$ values of $6.1 \mu \mathrm{M}$ against T. rubrum and $1.6 \mu \mathrm{M}$ against T. mentagrophytes, while the phenylethoxy analogue (24) had low activity against T. rubrum and an $\mathrm{IC}_{50}$ of $0.28 \mu \mathrm{M}$ against $T$. mentagrophytes. Lower activity for 23 has previously been reported. ${ }^{11}$ The vinyl sulfide analogue $18(1.3 \mu \mathrm{M})$ was as active as 17 against T. rubrum, but against $T$. mentagrophytes the $\mathrm{IC}_{50}(0.058 \mu \mathrm{M})$ was equal to that of griseofulvin (1).

The 3'-dimethyl analogue $\mathbf{5 2}$ was inactive against both fungi. The series of $3^{\prime}$ analogues include three $3^{\prime}$-iodo analogues with 2 ' modifications, 2'-methoxy (53), 2'-propoxy (54), and 2'benzyloxy (55). The 3'-iodo griseofulvin (53) was inactive against T. rubrum and had low activity toward T. mentagrophytes in accordance with Crosse et al. ${ }^{11}$ The 2 '-benzyloxy (55) analogue was inactive against T. rubrum and close to 20 times less potent $(1.1 \mu \mathrm{M})$ than $\mathbf{1}$ against T. mentagrophytes. Analogue $\mathbf{5 5}$ was also four times less potent than 17 , which has no $3^{\prime}$ iodo group. The propoxy (54) analogue showed activity against both fungi (T. rubrum $1.6 \mu \mathrm{M}$ and T. mentagrophytes $0.23 \mu \mathrm{M}$ ) but was less potent than both 1 and the analogue 46, which does not contain iodide. Analogue $\mathbf{5 4}$ has been reported to be the most potent at inducing curling of hyphae but less active against all dermatophytes spare one. ${ }^{11}$ 
The introduction of an oxime functionality on the parent compounds 1, 17, and 26 afforded the analogues 36, 37, and 38 and lowered the activity toward both fungi compared to the parent ketones (38 was inactive against both fungi altogether). The $\mathrm{IC}_{50}$ values for 36 were $1.3 \mu \mathrm{M}$ against T. rubrum and $0.19 \mu \mathrm{M}$ against T. mentagrophytes, which is in accordance with previously published data. ${ }^{13}$ Analogue 36 has also been reported active against $M$. gypseum. ${ }^{15}$ Compound 37 had $\mathrm{IC}_{50}$ values of $7.9 \mu \mathrm{M}$ against T. rubrum and of $0.30 \mu \mathrm{M}$ against T. mentagrophytes, 20 and 3 times less potent than $\mathbf{1}$, respectively. The 4' alcohol $\mathbf{5 0}$ exhibited low activity toward both fungi, which was not in agreement with prior work, as it has been reported that $\mathbf{5 0}$ causes $\mathbf{1 0 0 \%}$ growth inhibition of $T$. rubrum and visible inhibition against $T$. mentagrophytes at $28 \mu \mathrm{M}^{13}$ Compound $\mathbf{5 0}$ has however been tested inactive against $M$. gypseum. $^{15}$

The series including isogriseofulvin (3) and isogriseofulvin analogues 35 and 39-44 was inactive against T. rubrum and showed low activity against T. mentagrophytes. This is in accordance with the literature, where 3 and 39 have been reported to be less active than griseofulvin against a number of dermatophytes (E. floccosum, M. canis, T. interdigitale, T. persicolor, T. mentagrophytes, and T. rubrum).$^{11}$

Griseofulvic acid (2) was inactive against T. rubrum and had low activity against T. mentagrophytes contrary to prior work, which reported 2 to be inactive toward T. mentagrophytes but having visible growth inhibition at $30 \mu \mathrm{M}$ against T. rubrum. ${ }^{13}$ The griseofulvin dimer 34 was inactive against both fungi. The dichloro analogue 16 showed low activity toward both fungi, while $\mathbf{1 5}$ was inactive against both. The reduced analogue $\mathbf{5 1}$ had low activity against T. rubrum and an $\mathrm{IC}_{50}$ of $3.0 \mu \mathrm{M}$ against T. mentagrophytes, which is 50 times less potent compared to 1. Geodin (56) was inactive against both fungi.

Of the 55 compounds tested, 27 analogues were inactive or exhibited low activity for both fungi (see Table 1). Nine of the compounds were active against both fungi within the same order of magnitude compared to griseofulvin $(17,20,21,23$, $26,32,36,49$, and 54).

There were however some compounds that fared differently against the two fungi. The compounds $6,7,22,24,28,29$, 31, 51, and 55 were all inactive or had low activity toward T. rubrum but had $\mathrm{IC}_{50}$ values in the range of $0.25-3.0 \mu \mathrm{M}$ against T. mentagrophytes. For other analogues $(14,18,19,37$, 47, and 48 ) the activity against T. mentagrophytes was similar to that of $\mathbf{1}$ but against T. rubrum it was significantly lower. This is in accordance with earlier observations by Crosse et al., demonstrating that a given analogue was more active against some fungi but less active against others. ${ }^{11}$

Anticancer SAR. Looking at the $\mathrm{IC}_{50}$ values for the 16 analogues $(1,17,18,20,23-25,27,36,37,45-49$, and 54) tested active in both the multipolarity assay ${ }^{19}$ and the cytotoxicitybased assay there was good correlation between the data with an $R^{2}$ of 0.70 (see Supporting Information).

The $\mathrm{IC}_{50}$ of griseofulvin (1) was determined to be $18 \pm 4 \mu \mathrm{M}$ $(20 \pm 1 \mu \mathrm{M}$ in the phenotype-based spindle multipolarity assay $^{22}$ ), while an $\mathrm{IC}_{50}$ of $25 \pm 4 \mu \mathrm{M}$ against HeLa cells was found by Panda et al. ${ }^{18}$ In the position 4 series, 4, 5, and 7 were all inactive but 6 and 8 harboring aromatic moieties had activities similar to griseofulvin (1), with $\mathrm{IC}_{50}$ values of 20 (6) and $17 \mu \mathrm{M}(8)$. This indicates a mode of action for cytotoxicity that does not involve induction of multipolar mitosis, as 6 was inactive in the multipolarity assay. Both the position
5 analogues 9 and 10 were inactive in the cytotoxicity assay as they were in the assay for multipolarity induction.

The 6-phenol griseofulvic acid analogue 11 was inactive, and the 6-phenol griseofulvin analogue (13) showed low activity. The 6-ethyl griseofulvin (14) analogue was approximately 50\% less active than griseofulvin. The two dichloro analogues $\mathbf{1 5}$ and 16 were some of the most cytotoxic among the tested analogues, with $\mathrm{IC}_{50}$ values of 1.0 and $3.2 \mu \mathrm{M}$, respectively. 2'Chloro analogue 16 has previously been observed by us to have a different phenotype from all other analogues in the cell-based assay for multipolarity induction. ${ }^{22}$ The highly electrophilic nature of $\mathbf{1 6}$ prompted an investigation of the ability of this analogue, together with 1 and 17 , to act as Michael acceptors. Briefly, the three compounds were incubated in buffer with two different potential nucleophiles, 2-aminoethanol and 2-mercaptoethanol, for up to seven days (see Supporting Information for details). The experiments showed that neither 1 nor 17 underwent addition of the nucleophiles, whereas 16 did react with 2-mercaptoethanol to form the Michael addition/elimination product, which was the major constituent after $72 \mathrm{~h}$ of incubation. This confirms that the highly electron withdrawing properties of the chlorine atom enable 16 to react as a general alkylating agent and one could imagine the formation of a covalent bond to reactive cysteine residues in proteins. The experiment also shows that in the absence of the chlorine atom, this type of reactivity is not present for the griseofulvin analogues. Furthermore, the three representative compounds were found to be stable in the absence of nucleophiles for 1 week of incubation, showing only a slight decrease in purity.

When elongating the 2 ' position from the parent methoxy (1) to ethoxy (45) and propoxy (46) and then further increasing the bulkiness with isopropoxy (47), cyclopentoxy (49), and benzyloxy (17), the activity increased through the series (see Figure 3), plateauing with 17 and 49 at 2.1 and

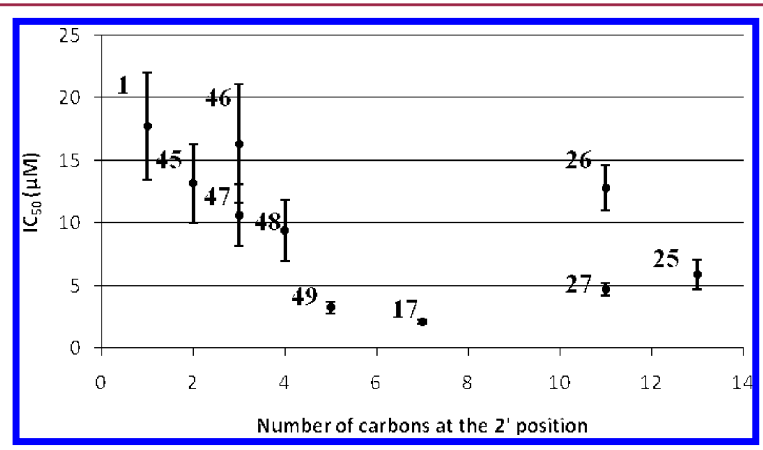

Figure 3. The activity increases with the number of carbon atoms at the $2^{\prime}$ position from griseofulvin itself to the $2^{\prime}$ ethoxy (45), propoxy (46), isopropoxy (47), and cyclopropylmethoxy (48) before leveling out with the cyclopentoxy (49) and benzyloxy (17) analogues. The bulkier analogues 25,27 , and 26 were less active than the benzyloxy analogue (17).

3.2 $\mu \mathrm{M}$, respectively. The same trend was seen when these compounds were tested in the phenotype-based multipolarity assay. Moving from the benzyloxy derived analogues to even bulkier groups like the naphthalen-1-ylmethoxy $(26,13 \mu \mathrm{M})$, biphenylmethoxy $(25,5.8 \mu \mathrm{M})$, and 1-adamantylmethoxy (27, 4.7 $\mu \mathrm{M})$ analogues, the activity did not increase further. The three compounds were still more potent than griseofulvin though, which was also observed for $\mathbf{2 5}$ and $\mathbf{2 7}$ in the phenotypebased assay. The trend seen for substituents of increasing size 
does not indicate that increasing lipophilicity also leads to increasing potency, which would be the case if transport over the cell membrane was a determining parameter for activity. This is further illustrated by the analogues 17, 23, and 24, where the former is the most active (Table 1), indicating that a binding event is responsible for the activity.

A number of variations of 17 have been tested (18-24, 2830, and 31-33), and although all except 33 (low activity), 28 $(32 \mu \mathrm{M})$, and $(24,17 \mu \mathrm{M} ; 30,19 \mu \mathrm{M})$ were more active than 1, only 20 was as active as 17 with an $\mathrm{IC}_{50}$ of $1.8 \mu \mathrm{M}$. The difference in activity between the phenoxy $(23,7.2 \mu \mathrm{M})$ and phenylethoxy $(24,17 \mu \mathrm{M})$ analogues was less pronounced in the cytotoxicity assay than in the multipolarity assay with two and a half orders of magnitude compared to the approximately 7-fold difference in the phenotype-based assay. The dimer (34) was about twice as active as 1 with an $\mathrm{IC}_{50}$ value of $8.5 \mu \mathrm{M}$.

The introduction of an oxime functionality at the 4 ' position (36) increased potency 2 -fold to $12 \mu \mathrm{M}$, an increase in activity that was also seen in the phenotype-based assay. Introducing the oxime to analogues $\mathbf{1 7}$ and 26 affording 37 and $38 \mathrm{im}$ proved the activity further for both compounds. Apart from 15, 37 is the most active analogue in the cytotoxicity assay with an $\mathrm{IC}_{50}$ of $1.4 \mu \mathrm{M}$. The stability of the oximes in PBS buffer ( $\mathrm{pH} 7.4)$ was tested, and less than $5 \%$ hydrolysis to the parent ketones could be detected after $48 \mathrm{~h}$ (data not shown).

The isogriseofulvin analogues tested in the multipolarity assay (3 and 39-44) were all inactive. In the cytotoxicity assay, 35 retained the activity of 1 , while the rest were either inactive (3), showed low activity $(39,44)$, or were less potent (40, $43 \mu \mathrm{M} ; 41,48 \mu \mathrm{M} ; 42,52 \mu \mathrm{M} ; 43,27 \mu \mathrm{M})$.

Geodin (56) did not induce multipolar mitoses and was in that respect deemed inactive. ${ }^{36}$ Geodin (56) is however twice as cytotoxic as griseofulvin when tested against the MDA-MB231 cell line, with an $\mathrm{IC}_{50}$ of $9.9 \mu \mathrm{M}$ opposed to $18 \mu \mathrm{M}$ for 1 .

The reduced analogues $\mathbf{5 0}$ and $\mathbf{5 1}$ as well as the 3'-dimethyl analogue $\mathbf{5 2}$ were inactive in both anticancer assays. In the $3^{\prime}$ iodo series, $53(22 \mu \mathrm{M})$ retained activity, the $2^{\prime}$ propoxy analogue $(\mathbf{5 4}, 8.0 \mu \mathrm{M})$ had increased activity, and $\mathbf{5 5}$ exhibited low activity. $\mathbf{5 3}$ and $\mathbf{5 5}$ were inactive in the phenotype-based assay, but 54 was more potent than 1 .

Anticancer SAR versus Antifungal SAR. The difference between the antifungal and anticancer data is illustrated in Figure 4, demonstrating that most of the analogues had

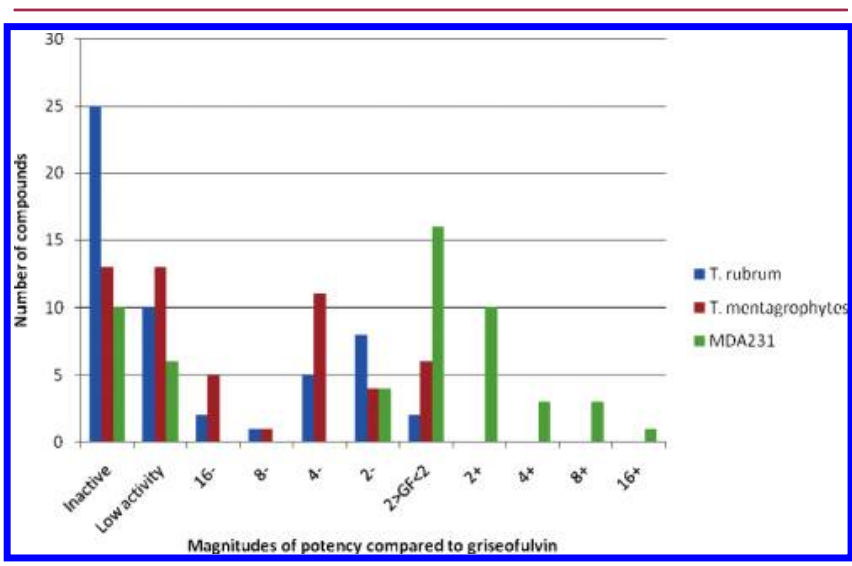

Figure 4. The $\mathrm{IC}_{50}$ values for each cell line have been normalized defining the activity of griseofulvin as having a value of 1 . It is seen that of the 53 analogues the majority was less active against the two fungi opposed to the anticancer activity where most analogues were more active than griseofulvin. increased potency against the cancer cell line but against the two fungal strains the activity was lower than for griseofulvin (1). Looking at the 4 position, there were inconsistencies throughout all three cell types. The ethyl analogue 5 was active against both fungi but inactive toward the cancer cells, while the bulkier naphtyl analogue 8 was inactive against both fungi but more potent than griseofulvin against the MDA-MB-231 cells. Analogues 6 and 7 were more potent than 5 against T. mentagrophytes, but both compounds were inactive or showed low activity toward T. rubrum. The most potent analogue toward the cancer cells (15) was inactive against both fungi and the isomer (16), which was among the most active compounds, only had low activity toward the two fungi. The two bulky analogues 25 and 27 as well as the dimer (34) were inactive in the antifungal assays but were all more potent than griseofulvin against the cancer cell line. It is also worth noticing that geodin (56) was inactive against both fungi but twice as potent as 1 against the cancer cell line.

The introduction of an oxime at the $4^{\prime}$ position $(36,37$, and 38 ) decreased the potency compared to the parent compounds $(1,17$, and 26) against both fungi. The opposite effect was seen for the cancer cell line, where the introduction of this moiety increased the activity for all three compounds.

There were however some similar trends for all three cell types. A number of analogues were inactive or had low activity toward both fungi and cancer cells. Among these were the position five analogues $(9,10)$, isogriseofulvin $(3)$, and the series of isogriseofulvin analogues $(39-44)$, with 35 as the sole exception. The two 6 phenols $(11,13)$ were virtually inactive against all cell types, which was the same for 50-52.

\section{CONCLUSION}

The first comparison of antifungal and anticancer SAR for griseofulvin analogues is presented in this work covering 53 analogues of griseofulvin as well as the natural product geodin (56). All compounds have been tested against T. rubrum, T. mentagrophytes, and in a cytotoxicity assay against MDA-MB231 breast cancer cells.

Even though there were similarities between the SAR of the two fungi, with some compounds showing no activity against both fungi and some active against both, there were also some differences. Analogues 46 and 48 retain the activity of griseofulvin against T. mentagrophytes but were 2- and 4-fold less active against $T$. rubrum than $\mathbf{1}$, respectively. This is in accordance with reported observations by Crosse et al. that analogues differ in activity against different dermatophytes. ${ }^{11}$

We show that there is a good correlation between the $\mathrm{IC}_{50}$ values from analogues that were active in both the phenotypebased assay for spindle multipolarity ${ }^{22}$ and the cytotoxicity assay used in this work with an $R^{2}$ of 0.70 . Comparing the two fungal SARs with the anticancer cytotoxicity SAR afforded distinct differences. The analogues $\mathbf{8}, \mathbf{2 5}, \mathbf{2 7}$, and 38 were inactive or had low potency against both fungi but either retained the activity (8) or were at least 2 -fold more active against the cancer cells compared to 1 . The 2 -benzyloxy analogue (17) was less active against both fungi in this study and against six dermatophytes in the study by Crosse et al. ${ }^{11}$ This analogue is however nine times more potent than $\mathbf{1}$ against the cancer cell line MDA-MB-231. It is noteworthy that the two dichloro compounds 15 and 16 were inactive against both fungi but featured as some of the most cytotoxic agents against the cancer cell line, possibly due to their electrophilic nature, which is unique among the tested analogues. 
The differences in activity observed for the two fungi and the MDA-MB-231 cell line could rise from a number of factors, such as transport over the cell membrane, efflux pumps, or different modes of action. We find it unlikely that transport or efflux pumps could explain that the majority of analogues were more active against MDA-MB-231 cells and less active against both fungi. Our conclusion therefore is that the mode-of-action of griseofulvin(s) toward fungal and mammalian cells is different, making it unlikely that tubulin itself constitutes the main cellular target in both fungi and mammalian cells. Because it has been shown that griseofulvin leads to mitotic arrest in both fungal and mammalian cells, an alternative explanation is that griseofulvin disrupts microtubule dynamics without directly interacting with tubulin, e.g., through interaction with microtubule-associated proteins (MAPs).

\section{EXPERIMENTAL SECTION}

General. Starting materials, reagents, and solvents were purchased from Sigma-Aldrich and used without further purification. ${ }^{1} \mathrm{H}$ NMR spectra were recorded using either a Varian Unity Inova $500 \mathrm{MHz}$ spectrometer or a Varian Mercury $300 \mathrm{MHz}$ spectrometer both from Agilent (Santa Clara, CA, US). ${ }^{13} \mathrm{C}$ NMR spectra were recorded using either a Varian Mercury $300 \mathrm{MHz}$ or a Bruker AC $200 \mathrm{MHz}$ from Bruker Optics (Ettlingen, Germany). Chemical shifts were measured in ppm and coupling constants in $\mathrm{Hz}$. When $\mathrm{CDCl}_{3}$ was used as solvent, the residual peak was used as internal reference at $\delta 7.27$ for ${ }^{1} \mathrm{H}$ NMR and $\delta 77.00$ for ${ }^{13} \mathrm{C}$ NMR spectra. IR spectra were recorded using a Bruker Alpha ATR and measured in $\mathrm{cm}^{-1}$. All melting points are uncorrected. TLC was performed on aluminum sheets precoated with silica gel 60 F254 (Merck 1.05554.0001). Compounds were visualized by charring after dipping in a solution of $1 \% \mathrm{KMnO}_{4}, 6.7 \%$ $\mathrm{K}_{2} \mathrm{CO}_{3}$, and $0.08 \% \mathrm{NaOH}$ in water. $\mathrm{UV}$ visualization was done using a model UVGL-25 Mineralight lamp. High-resolution LC-DAD-MS was performed on an Agilent 1100 system equipped with a photodiode array detector (DAD) and coupled to a LCT orthogonal time-of-flight mass spectrometer (Waters-Micromass, Manchester, UK) with a Z-spray electrospray ionization (ESI) source and a LockSpray probe ( $\mathrm{M}+\mathrm{H}$ 556.2771) and controlled by MassLynx 4.0 software. LC-MS calibration from $\mathrm{m} / z$ 100-900 was done with a PEG mixture. Standard separation involved a LUNA 2 column with an acetonitrile (50 ppm TFA) in water gradient starting from $15 \%$ to $100 \%$ over $25 \mathrm{~min}$ with a flow rate of $0.3 \mathrm{~mL} / \mathrm{min}$. Purity of all compounds was found to be greater than $95 \%$ by LC-DAD. Microanalyses were obtained from $\mathrm{H}$. Kolbe Mikroanalytisches Laboratorium in Mülheim an der Ruhr, Germany. The purity of all tested compounds was found to be $>95 \%$ by HPLC

Antifungal Assay. The fungal micro broth dilution assay was performed in sterile flat bottomed microplates (cat. no. 655101) and lids (cat. no. 656161) from Greiner Bio-One GmbH (Frickenhausen, Germany). Each microplate accommodated five dilution series starting at $50 \mu \mathrm{M}$ of a given analogue. Each plate was also fitted with four negative and four positive control wells. The fungi $T$. rubrum (IBT29284) and T. mentagrophytes (IBT2724) were kept in the IBT fungal collection at the Department of Systems Biology at the Technical University of Denmark. The identity of the fungal cultures was verified by microscopy after the last test round in the antifungal assay. For testing against T. rubrum, a 4-fold dilution series was used, resulting in 10 concentrations with the lowest at $0.2 \mu \mathrm{M}$. For T. mentagrophytes, an 8-fold dilution series was used, resulting in 10 concentrations with the last one at $0.4 \mathrm{pM}$.

Inoculum preparation was performed in accordance with the document M38-A2 ${ }^{38}$ from the "Committee for Clinical Laboratory Standards". Inoculum was adjusted to $0.90-1.5 \mathrm{OD}$ at $530 \mathrm{nM}$ on a Genesys 10uv from Thermo Electron Corporation (Waltham, MA, US). The inoculums were diluted 50-fold with RPMI media (with L-glutamine, without $\mathrm{NaHCO}_{3}$, cat. no. R6504 in MOPS buffer (cat. no.69947)), both from Sigma-Aldrich (St Louis, MO, USA). The $\mathrm{pH}$ was adjusted to 7.00 with $1 \mathrm{M} \mathrm{NaOH}$, and the volume with Milli-Q water from a Milli-Q gradient fitted with a Millipore $0.22 \mu \mathrm{m}$ filter (cat. no. MPGL04001), both from Millipore (Billerica, MA, USA).

Each well contained $99 \mu \mathrm{L}$ of RPMI media with inoculum, $99 \mu \mathrm{L}$ of Milli-Q water, and $2 \mu \mathrm{L}$ of DMSO. Microplates were incubated for 7 days at $37^{\circ} \mathrm{C}$ in a WTB binder incubator from VWR (Radnor, PA, US), at which point the OD of the wells were measured at $530 \mu \mathrm{M}$ on a BioTek Synergy 2 (Brøndby, Denmark) using Gen5TM 1.10.8 software. The half-maximal inhibitory concentration $\left(\mathrm{IC}_{50}\right)$ values were obtained with GraphPad Prism5 (ver. 5.04) from GraphPad Software (La Jolla, CA, USA) using the "nonlinear regression, sigmoidal dose-response (variable slope)" function. The fitting method used was "automatic outlier elimination", ${ }^{39}$ which eliminated less than $1.1 \%$ of data points.

Cytotoxicity Assay. MDA-MBA-231 human adenocarcinoma cells were cultivated in Leibovitz's L-15 medium in the presence of $10 \%$ fetal calf serum at $37^{\circ} \mathrm{C}$. Cell viability was examined using the 3-(4,5dimethylthiazol-2-yl)-2,5-diphenyltetrazoliumbromide (MTT; Sigma Chemical, St. Louis, MO) colorimetric assay, as previously described. ${ }^{40}$ Briefly, cells were plated in 96-well microtiter plates at a density of $(2-3) \times 104$ cells per well, and each plate was incubated for 24 and/or $48 \mathrm{~h}$, with MTT added to each well for at least $4 \mathrm{~h}$. The absorbance of each well was measured at $570 / 630 \mathrm{~nm}$ using a spectrophotometer (Molecular Devices, Sunnyvale, CA). Each condition was analyzed in at least three replicates, and the results are presented as the mean \pm standard deviation of replicates of a representative experiment that was repeated at least three times.

General Procedure for the Synthesis of Position 4 Ethers (7 and 8$)$. The appropriate alkyl bromide ( $1.2 \mathrm{mmol}, 3$ equiv) was added to a solution of 4 ( $0.4 \mathrm{mmol}, 1$ equiv), $\mathrm{Ag}_{2} \mathrm{O}$ ( $1.2 \mathrm{mmol}, 3$ equiv), and 1,4-dioxane $(5 \mathrm{~mL})$. The mixture was stirred at $50{ }^{\circ} \mathrm{C}$ for $18 \mathrm{~h}$ and then cooled to $20^{\circ} \mathrm{C}$. EtOAc $(10 \mathrm{~mL})$ was added to the solution, and the mixture was washed with brine $(15 \mathrm{~mL})$. The aqueous phase was extracted with EtOAc $(2 \times 10 \mathrm{~mL})$, and the combined organic phases were dried $\left(\mathrm{MgSO}_{4}\right)$ and concentrated. The residue was purified by column chromatography (EtOAc:heptane 1:3) to afford the desired product.

(2S,6'R)-(7-Chloro-6-ethoxy-4-methoxy-benzofuran-3-one)2-spiro-1'-(2'-methoxy-6'-methyl-cyclohex-2'-ene-4'-one) 14. Ethyl bromide (0.9 mmol, 3 equiv) was added to a solution of 12 (0.3 mmol, 1 equiv), $\mathrm{Ag}_{2} \mathrm{O}$ (0.9 mmol, 3 equiv), and 1,4-dioxane $(3 \mathrm{~mL})$. The mixture was stirred at $50^{\circ} \mathrm{C}$ for $18 \mathrm{~h}$ and then cooled to $20^{\circ} \mathrm{C}$. EtOAc $(10 \mathrm{~mL})$ was added to the solution, and the mixture was washed with brine $(15 \mathrm{~mL})$. The aqueous phase was extracted with EtOAc $(2 \times 10 \mathrm{~mL})$, and the combined organic phases were dried $\left(\mathrm{MgSO}_{4}\right)$ and concentrated. The following process was repeated three times: The residue was dissolved in $\mathrm{MeOH}(10 \mathrm{~mL}), \mathrm{CSA}(0.1 \mathrm{mmol})$ was added, and the mixture was heated to $65{ }^{\circ} \mathrm{C}$ for $18 \mathrm{~h}$. EtOAc $(10 \mathrm{~mL})$ was added to the solution, and the mixture was washed with satd aq $\mathrm{NaHCO}_{3}(15 \mathrm{~mL})$. The aqueous phase was extracted with EtOAc $(2 \times 10 \mathrm{~mL})$, and the combined organic phases were dried $\left(\mathrm{MgSO}_{4}\right)$ and concentrated. The residue was purified by column chromatography (EtOAc:heptane 1:3) to afford the desired product 14. Yield, $5 \mathrm{mg}$ (5\%) (yellow oil); $R_{\mathrm{f}}$ value (EtOAc/heptane, $5: 1$ ), 0.43. IR (neat, $\left.\mathrm{cm}^{-1}\right): 1709,1666,1613,1587$ (lit. $^{41}$ ). ${ }^{1} \mathrm{H}$ NMR $\left(\mathrm{CDCl}_{3}, 300 \mathrm{MHz}\right): \delta 6.13(1 \mathrm{H}, \mathrm{s}), 5.56(1 \mathrm{H}, \mathrm{s}), 4.25(2 \mathrm{H}, \mathrm{q}, J=$ $7.0 \mathrm{~Hz}), 3.98(3 \mathrm{H}, \mathrm{s}), 3.63(3 \mathrm{H}, \mathrm{s}), 3.05(1 \mathrm{H}, \mathrm{dd}, J=16.7,13.4 \mathrm{~Hz})$, $2.86(1 \mathrm{H}),, 2.45(1 \mathrm{H}, \mathrm{dd}, J=16.7,4.7 \mathrm{~Hz}), 1.56(3 \mathrm{H}, \mathrm{t}, J=7.0 \mathrm{~Hz})$, $0.98(3 \mathrm{H}, \mathrm{d}, J=6.7 \mathrm{~Hz}) .{ }^{13} \mathrm{C} \mathrm{NMR}\left(\mathrm{CDCl}_{3}, 50 \mathrm{MHz}\right): \delta 197.0,192.4$, $170.8,169.6,164.1,157.7,104.9$ (2C), 93.4, 90.7, 90.2, 65.8, 56.6, 56.3, 40.1, 36.4, 14.6, 14.2; $[\alpha]^{20}{ }_{\mathrm{D}}=+252^{\circ}\left(c=0.5\right.$ in $\left.\mathrm{CCl}_{3}\right)\left(\mathrm{Lit.}^{27}\right)$. HRMS $\left(\mathrm{ESI}^{+}\right)$calcd for $[\mathrm{M}+\mathrm{H}]^{+}\left[\mathrm{C}_{18} \mathrm{H}_{20} \mathrm{ClNO}_{6}\right]^{+} 367.0948$, found 367.0949 .

General Procedure for the Synthesis of 2' Enol Ethers (19, $21,22,26,28-33)$. To a solution of $16(0.65 \mathrm{mmol}, 1$ equiv $)$ in 1,4 dioxane $(3 \mathrm{~mL}, 0.2 \mathrm{M})$ was added the desired alcohol $(1.30 \mathrm{mmol}$, 2 equiv) and $\mathrm{DBU}(1.63 \mathrm{mmol}, 2.5$ equiv). The mixture was heated to $100{ }^{\circ} \mathrm{C}$ and stirred for $12 \mathrm{~h}$. The mixture was then cooled to $20^{\circ} \mathrm{C}$, and excess reagent was quenched with satd aq $\mathrm{NH}_{4} \mathrm{Cl}(30 \mathrm{~mL})$. The aqueous phase was extracted with EtOAc $(3 \times 30 \mathrm{~mL})$, and the combined organic phases were dried $\left(\mathrm{MgSO}_{4}\right)$ and concentrated. The 
residue was purified by column chromatography (EtOAc:heptane: 1:3) affording the product. When possible, the product was recrystallized from $\mathrm{EtOAc} /$ heptane.

(2S,6'R)-(7-Chloro-4,6-dimethoxy-benzofuran-3-one)-2spiro-1' $-\left(2^{\prime}\right.$-(naphthalen-1-ylmethoxy)-6'-methylcyclohex-2' ene-4'-one-4'-oxime) 38. To a solution of $26(0.08 \mathrm{mmol}, 1.0$ equiv) in EtOH $(2 \mathrm{~mL})$ and DMSO $(1 \mathrm{~mL})$ was added hydroxylamine hydrochloride ( $0.30 \mathrm{mmol}, 3.5$ equiv) and sodium acetate $(0.37 \mathrm{mmol}$, 4.3 equiv). The mixture was stirred at $75^{\circ} \mathrm{C}$ for $18 \mathrm{~h}$, allowed to reach $20^{\circ} \mathrm{C}$, and diluted with EtOAc $(5 \mathrm{~mL})$. The mixture was washed with brine $(3 \times 4 \mathrm{~mL})$. The organic phase was dried $\left(\mathrm{MgSO}_{4}\right)$ and concentrated. The crude mixture was purified by column chromatography (EtOAc:heptane 1:1) to afford 38 (40 $\mathrm{mg}, 96 \%)$ as a yellow oil. $R_{\mathrm{f}}$ values (EtOAc/heptane, 5:1), 0.60 and 0.51. IR (neat, $\mathrm{cm}^{-1}$ ): 1704 , 1613, 1590. ${ }^{1} \mathrm{H}$ NMR $\left(500 \mathrm{MHz}, \mathrm{CDCl}_{3}\right): \delta 7.82-7.73(3 \mathrm{H}, \mathrm{m})$, $7.50-7.42(2 \mathrm{H}, \mathrm{m}), 7.37-7.32(2 \mathrm{H}, \mathrm{m}), 6.54(0.4 \mathrm{H}, \mathrm{s}), 5.99(0.6 \mathrm{H}, \mathrm{s})$, $5.96(0.4 \mathrm{H}, \mathrm{s}), 5.84(0.6 \mathrm{H}, \mathrm{s}), 5.31(0.4 \mathrm{H}, \mathrm{d}, J=12.0 \mathrm{~Hz}), 5.29(0.6 \mathrm{H}$, $\mathrm{d}, J=12.0 \mathrm{~Hz}), 5.26(0.4 \mathrm{H}, \mathrm{d}, J=11.9 \mathrm{~Hz}), 5.23(0.6 \mathrm{H}, \mathrm{d}, J=11.9$ $\mathrm{Hz}), 3.95(1.8 \mathrm{H}, \mathrm{s}), 3.93(1.2 \mathrm{H}, \mathrm{s}), 3.91(1.8 \mathrm{H}, \mathrm{s}), 3.90(1.2 \mathrm{H}, \mathrm{s}), 3.15$ $(0.6 \mathrm{H}, \mathrm{dd}, J=16.8,4.9 \mathrm{~Hz}), 3.06(0.4 \mathrm{H}, \mathrm{dd}, J=15.0,13.3 \mathrm{~Hz}), 2.75$ $(0.6 \mathrm{H}, \mathrm{dd}, J=16.8,13.1 \mathrm{~Hz}), 2.70-2.57(1 \mathrm{H}, \mathrm{m}), 2.44(0.4 \mathrm{H}, \mathrm{dd}$, $J=15.0,4.1 \mathrm{~Hz}), 0.98(1.8 \mathrm{H}, \mathrm{d}, J=6.7 \mathrm{~Hz}), 0.98(1.2 \mathrm{H}, \mathrm{d}, 6.8 \mathrm{~Hz})$. ${ }^{13} \mathrm{C}$ NMR $\left(75 \mathrm{MHz}, \mathrm{CDCl}_{3}\right): \delta 194.0(0.5 \mathrm{C}, \mathrm{s}), 193.9(0.5 \mathrm{C}, \mathrm{s}), 169.3$ (0.5C, s), 164.0 (0.5C, s), 160.0 (0.5C, s), 157.3 (0.5C, s), 157.3 (0.5C, s), 157.3 (0.5C, s), $155.0(0.5 \mathrm{C}, \mathrm{s}), 151.8(0.5 \mathrm{C}, \mathrm{s}), 133.3$ (0.5C, s), $131.2(0.5 \mathrm{C}, \mathrm{s}), 131.1(0.5 \mathrm{C}, \mathrm{s}), 130.8$ (0.5C, s), 130.6 (0.5C, s), 128.9 (0.5C, s), 128.9 (0.5C, s), 128.8 (0.5C, s), 128.3 (0.5C, s), $128.2(0.5 \mathrm{C}, \mathrm{s}), 128.1$ (0.5C, s), 126.3 (0.5C, s), 126.3 (0.5C, s), $126.2(0.5 \mathrm{C}, \mathrm{s}), 126.0(0.5 \mathrm{C}, \mathrm{s}), 125.7$ (0.5C, s), 125.6 $(0.5 \mathrm{C}, \mathrm{s}), 125.2(0.5 \mathrm{C}, \mathrm{s}), 125.0(0.5 \mathrm{C}, \mathrm{s}), 124.9(0.5 \mathrm{C}, \mathrm{s}), 123.6$ (0.5C, s), 123.5 (0.5C, s), $105.6(0.5 \mathrm{C}, \mathrm{s}), 105.5$ (0.5C, s), 100.5 (0.5C, s), 96.9 (0.5C, s), $96.8(0.5 \mathrm{C}, \mathrm{s}), 93.9$ (0.5C, s), 91.5 (0.5C, s), $91.4(0.5 \mathrm{C}, \mathrm{s}), 89.0$ (0.5C, s), 89.0 (0.5C, s), 69.4 (0.5C, s), 69.0 $(0.5 \mathrm{C}, \mathrm{s}), 56.7$ (1 C, s), $56.1(0.5 \mathrm{C}, \mathrm{s}), 56.1(0.5 \mathrm{C}, \mathrm{s}), 36.4(0.5 \mathrm{C}, \mathrm{s})$, $35.2(0.5 \mathrm{C}, \mathrm{s}), 30.9(0.5 \mathrm{C}, \mathrm{s}), 25.5$ (0.5C, s), 14.4 (0.5 C, s), 14.3 $(0.5 \mathrm{C}, \mathrm{s}) ;[\alpha]^{20}=+112^{\circ}\left(c=1.0\right.$ in $\left.\mathrm{CDCl}_{3}\right)$. HRMS (ESI+) calcd for $\mathrm{M}+\mathrm{H}\left[\mathrm{C}_{27} \mathrm{H}_{25} \mathrm{ClNO}_{6}\right]^{+}$494.1370, found 494.1371.

The analogue 35 was synthesized according to the general procedure for 2 ' enol ethers with the starting material being 15 instead of 16.

$\left(2 S, 6^{\prime} R\right)$-(7-Chloro-4,6-dimethoxy-benzofuran-3-on)-2-spiro1'-(4'-(3-methoxybenzyl)oxy-6'-methyl-cyclohex-3'-en-2' one] 35. Yield: $83 \mathrm{mg}$ (32\%) (white crystals); $\mathrm{R}_{f}$ value (EtOAc/ heptane, 5:1): 0.65 ; mp $173-175{ }^{\circ} \mathrm{C}$. IR (neat, $\mathrm{cm}^{-1}$ ): 1691, 1653, 1605, 1584. ${ }^{1} \mathrm{H}$ NMR $\left(\mathrm{CDCl}_{3}, 300 \mathrm{MHz}\right): \delta 7.37-7.27(1 \mathrm{H}, \mathrm{m})$, $7.02-6.84(3 \mathrm{H}, \mathrm{m}), 6.09(1 \mathrm{H}, \mathrm{s}), 5.54(1 \mathrm{H}, \mathrm{d}, J=1.0 \mathrm{~Hz}), 5.01-4.85$ $(2 \mathrm{H}, \mathrm{m}), 4.01(3 \mathrm{H}, \mathrm{s}), 3.93(3 \mathrm{H}, \mathrm{s}), 3.84(3 \mathrm{H}, \mathrm{s}), 3.26(1 \mathrm{H}, \mathrm{ddd}, J=$ $17.5,11.9,1.0 \mathrm{~Hz}), 2.96-2.80(1 \mathrm{H}, \mathrm{m}), 2.54(1 \mathrm{H}, \mathrm{dd}, J=17.5$, $5.6 \mathrm{~Hz}), 1.03(3 \mathrm{H}, \mathrm{d}, J=6.6 \mathrm{~Hz}) \cdot{ }^{13} \mathrm{C} \mathrm{NMR}\left(\mathrm{CDCl}_{3}, 50 \mathrm{MHz}\right): \delta$ $191.7,188.8,177.7,169.7,164.5,159.9,157.7,136.0,129.7,120.0$, $114.2,113.2,105.1,100.7,97.3,95.1,89.5,71.0,57.0,56.2,55.3,35.2$, $33.214 .5 ;[\alpha]^{20}{ }_{\mathrm{D}}=+179^{\circ}\left(c=0.6\right.$ in $\left.\mathrm{CCl}_{3}\right)$. HRMS $\left(\mathrm{ESI}^{+}\right)$calcd for $[\mathrm{M}+\mathrm{H}]^{+}\left[\mathrm{C}_{24} \mathrm{H}_{24} \mathrm{ClO}_{7}\right]^{+} 459,1211$, found 459.1216.

General Procedure for the Synthesis of Enol Ethers by Solvolysis (42 and 43). CSA ( $0.1 \mathrm{mmol}, 0.1$ equiv) was added to a solution of griseofulvic acid ( $0.6 \mathrm{mmol}, 1$ equiv) in the appropriate alcohol $(6 \mathrm{~mL}, 0.1 \mathrm{M})$. The mixture was stirred at $100{ }^{\circ} \mathrm{C}$ for $6 \mathrm{~h}$ and then cooled to $20^{\circ} \mathrm{C}$. EtOAc $(20 \mathrm{~mL})$ was added to the solution, and the mixture was washed with satd aq $\mathrm{NaH}_{2} \mathrm{PO}_{4}(20 \mathrm{~mL})$ and water $(20 \mathrm{~mL})$. The combined aqueous phases were extracted with EtOAc $(3 \times 20 \mathrm{~mL})$, and the combined organic phases were dried $\left(\mathrm{MgSO}_{4}\right)$ and concentrated. The residue was purified by column chromatography (toluene: $\mathrm{CH}_{2} \mathrm{Cl}_{2}: \mathrm{EtOAc} 7: 7: 1$ ) to afford the desired products. When possible, the products were recrystallized from EtOAc/heptane.

\section{ASSOCIATED CONTENT}

\section{S Supporting Information}

Full experimental data for compounds 3, 7, 8, 19, 21, 22, 26, 28-34, and 39-44, as well as copies of NMR spectra for compounds $3,7,8,15,19,21,22,26,28-35$, and 38-44. This material is available free of charge via the Internet at http:// pubs.acs.org.

\section{AUTHOR INFORMATION}

\section{Corresponding Author}

*For T.O.L.: phone, +45 4525 2632; E-mail, tol@bio.dtu.dk. For M.H.C.: phone, +45 4525 2131; E-mail, mhc@kemi.dtu.dk.

\section{ACKNOWLEDGMENTS}

We thank Anja Irsigler, Christine Immel, and Sigrid Heil for cytotoxicity assay testing. We thank Brian Dideriksen for assistance with stability studies. We thank the Danish Research Council (reference no. 274-07-0561), the Deutsche Krebshilfe (grant no. 107739), and the Karen Krieger Foundation for financial support.

\section{ABBREVIATIONS USED}

CSA, camphor sulfonic acid; DBU, 1,8-diazabicyclo[5.4.0]undec-7-ene; MAP, microtubule-associated protein; PBS, phosphate-buffered saline; SAR, structure-activity relationship

\section{REFERENCES}

(1) Oxford, A. E.; Raistrick, H.; Simonart, P. Studies in the biochemistry of micro-organisms. LX. Griseofulvin, $\mathrm{C}_{17} \mathrm{H}_{17} \mathrm{O}_{6} \mathrm{Cl}$, a metabolic product of Penicillium griseo-fulvum Dierckx. Biochem. J. 1939, 33, 240-248.

(2) Gentles, J. C. Experimental Ringworm in Guinea Pigs-Oral Treatment with Griseofulvin. Nature 1958, 182, 476-477.

(3) Williams, D. I.; Marten, R. H.; Sarkany, I. Oral Treatment of Ringworm with Griseofulvin. Lancet 1958, 2, 1212-1213.

(4) Alles, R.; Bekker, D.; Bonni, Z.; Khirsh, S.; Kal, B. O.; Kelle, E. U. L. R.; Majer, F. K.; Shtjutts, A.; Uill, J. A. Terbinafine Solid Medicinal Formulation for Oral Administration. Russian Patent RU2298402, 2007.

(5) Terbinafine. FDA: Washington, DC, 11/11/2011; http://www. fda.gov/ForConsumers/ConsumerUpdates/ucm048710.htm.

(6) Gupta, A. K.; Summerbell, R. C. Tinea capitis. Med. Mycol. 2000, $38,255-287$.

(7) Seebacher, C.; Abeck, D.; Brasch, J.; Cornely, O.; Daeschlein, G.; Effendy, I.; Ginter-Hanselmayer, G.; Haake, N.; Hamm, G.; Hipler, C.; Hof, H.; Korting, H. C.; Kramer, A.; Mayser, P.; Ruhnke, M.; Schlacke, K. H.; Tietz, H. J. Tinea capitis: ringworm of the scalp. Mycoses 2007, $50,218-226$.

(8) Sobue, S.; Sekiguchi, K.; Nabeshima, T. Intracutaneous distributions of fluconazole, itraconazole, and griseofulvin in guinea pigs and binding to human stratum corneum. Antimicrob. Agents Chemother. 2004, 48, 216-223.

(9) Chaudhuri, A. R.; Ludueña, R. F. Griseofulvin: Interaction With Normal and Subtilisin-Treated Tubulin. Drug Dev. Res. 2001, 53, 44-49.

(10) Wehland, J.; Herzog, W.; Weber, K. Interaction of Griseofulvin with Microtubules, Microtubule Protein and Tubulin. J. Mol. Biol. 1977, 111, 329-342.

(11) Crosse, R.; Rhodes, A.; Mcwillia, R. Some Relations between Chemical Structure and Antifungal Effects of Griseofulvin Analogues. J. Gen. Microbiol. 1964, 34, 51-65.

(12) Crowdy, S. H.; Grove, J. F.; McCloskey, P. Translocation of Antibiotics in Higher Plants 0.4. Systemic Fungicidal Activity and Chemical Structure in Griseofulvin Relatives. Biochem. J. 1959, 72, 241-249.

(13) Delgado, L.; De Croos, P. Z.; Lu, M. C. H.; Currie, B. L. Structure Modification and Biological Activity of Some Griseofulvin Derivatives. Kaohsiung J. Med. Sci. 1992, 8, 632-639.

(14) Yamato, M.; Yoshida, H.; Ikezawa, K.; Kohashi, Y. Synthesis of a Griseofulvin Analogue. Chem. Pharm. Bull. 1986, 34, 71-76. 
(15) Fischer, L. J.; Riegelman, S. Absorption and Activity of Some Derivatives of Griseofulvin. J. Pharm. Sci. 1967, 56, 469-476.

(16) Use of Griseofulvin for Inhibiting the Growth of Cancers. (The Proctor \& Gamble Company) . Patent WO9705870A2, 1997.

(17) Ho, Y. S.; Duh, J. S.; Jeng, J. H.; Wang, Y. J.; Liang, Y. C.; Lin, C. H.; Tseng, C. J.; Yu, C. F.; Chen, R. J.; Lin, J. K. Griseofulvin potentiates antitumorigenesis effects of nocodazole through induction of apoptosis and G2/M cell cycle arrest in human colorectal cancer cells. Int. J. Cancer 2001, 91, 393-401.

(18) Panda, D.; Rathinasamy, K.; Santra, M. K.; Wilson, L. Kinetic suppression of microtubule dynamic instability by griseofulvin: implications for its possible use in the treatment of cancer. Proc. Natl. Acad. Sci. U.S.A. 2005, 102, 9878-9883.

(19) Rebacz, B.; Larsen, T. O.; Clausen, M. H.; Rønnest, M. H.; Loffler, H.; Ho, A. D.; Krämer, A. Identification of griseofulvin as an inhibitor of centrosomal clustering in a phenotype-based screen. Cancer Res. 2007, 67, 6342-6350.

(20) Jin, H.; Yamashita, A.; Maekawa, S.; Yang, P. T.; He, L. M.; Takayanagi, S.; Wakita, T.; Sakamoto, N.; Enomoto, N.; Ito, M. Griseofulvin, an oral antifungal agent, suppresses hepatitis $\mathrm{C}$ virus replication in vitro. Hepatol. Res. 2008, 38, 909-918.

(21) Oda, T. Effects of 2'-Demethoxy-2'-propoxygriseofulvin on Microtubule Distribution in Chinese Hamster V79 cells. J. Antibiot. 2006, 59, 114-116.

(22) Rønnest, M. H.; Rebacz, B.; Markworth, L.; Terp, A. H.; Larsen, T. O.; Krämer, A.; Clausen, M. H. Synthesis and Structure-Activity Relationship of Griseofulvin Analogues as Inhibitors of Centrosomal Clustering in Cancer Cells. J. Med. Chem. 2009, 52, 3342-3347.

(23) Grisham, L. M.; Wilson, L.; Bensch, K. G. Antimitotic Action of Griseofulvin does not Involve Distruption of Microtubules. Nature 1973, 244, 294-296.

(24) Zomorodian, K.; Uthman, U.; Tarazooie, B.; Rezaie, S. The effect of griseofulvin on the gene regulation of alpha-tubulin in the dermatophyte pathogen Trichophyton rubrum. J. Infect. Chemother 2007, 13, 373-379.

(25) Rathinasamy, K.; Jindal, B.; Asthana, J.; Singh, P.; Balaji, P. V.; Panda, D. Griseofulvin stabilizes microtubule dynamics, activates p53 and inhibits the proliferation of MCF-7 cells synergistically with vinblastine. BMC Cancer 2010, 10, 213.

(26) Ganem, N. J.; Godinho, S. A.; Pellman, D. A mechanism linking extra centrosomes to chromosomal instability. Nature 2009, 460, 278283.

(27) Arkley, V.; Gregory, G. I.; Attenbur, J.; Walker, T. Griseofulvin Analogues. Part I. Modification of the Aromatic Ring. J. Chem. Soc. 1962, 1260-1268.

(28) Arkley, V.; Walker, T.; Gregory, G. I. Griseofulvin Analogues. Part VI. Dechlorogriseofulvin and Some of Its Derivatives. J. Chem. Soc. 1963, 1603-1610.

(29) Rønnest, M. H.; Harris, P.; Gotfredsen, C. H.; Larsen, T. O.; Clausen, M. H. Synthesis and single crystal X-ray analysis of two griseofulvin metabolites. Tetrahedron Lett. 2010, 51, 5881-5882.

(30) Process of Preparing Griseofulvic Acid. (Glaxo Group Limited) U.S. Patent US3102122, 1959.

(31) Stephenson, L.; Walker, T.; Warburton, W. K. A.; Webb, G. B. Griseofulvin Analogues. Part IV. The Preparation and Properties of Some Chlorides. J. Chem. Soc. 1962, 1282-1292.

(32) Grove, J. F.; MacMillan, J.; Mulholland, T. P. C; Rogers, M. A. T. Griseofulvin. Part 1. J. Chem. Soc. 1952, 3949-3958.

(33) Clausen M. H.; Krämer A.; Laresen T. O.; Rebacz B. Griseofulvin Analogues for the Treatment of Cancer by Inhibition of Centrosomal Clustering. Patent WO 2009000937, 2008.

(34) Preparation of griseofulvin analogs for the treatment of cancer by inhibition of centrosomal clustering. Patent WO2010072770, 2010.

(35) Yamato, M. Preparation of griseofulvin derivatives. Jpn. Kokai Tokkyo Koho . JP 03255081, 1991.

(36) Rønnest, M. H.; Nielsen, M. T.; Leber, B.; Mortensen, U. H.; Krämer, A.; Clausen, M. H.; Larsen, T. O.; Harris, P. (+)-Geodin from Aspergillus terreus. Acta Crystallogr., Sect. C: Cryst. Struct. Commun. 2011, 67, O125-O128.
(37) Takeuchi, Y.; Watanabe, I.; Misumi, K.; Irie, M.; Hirose, Y.; Hirata, K.; Yamato, M.; Harayama, T. Syntheses and Antifungal Activity of DL-Griseofulvin and Its Congeners. III. Chem. Pharm. Bull. 1997, 45, 2011-2015.

(38) Reference Method for Broth Dilution Antifungal Susceptibility Testing of Filamentous Fungi; Approved Standard M38-A2; National Committee for Clinical Laboratory Standards: Wayne, PA, 2002.

(39) Motulsky, H. J.; Brown, R. E. Detecting outliers when fitting data with nonlinear regression-a new method based on robust nonlinear regression and the false discovery rate. BMC Bioinform. 2006, 7, 123.

(40) Hideshima, T.; Chauhan, D.; Hayashi, T.; Podar, K.; Akiyama, M.; Mitsiades, C.; Mitsiades, N.; Gong, B.; Bonham, L.; de Vries, P.; Munshi, N.; Richardson, P. G.; Singer, J. W.; Anderson, K. C. Antitumor activity of lysophosphatidic acid acyltransferase-beta inhibitors, a novel class of agents, in multiple myeloma. Cancer Res. 2003, 63, 8428-8436.

(41) Page, J. E.; Staniforth, S. E. Griseofulvin Analogues. Part V. Infrared Absorption. J. Chem. Soc. 1962, 1292-1303. 